SPECIAL ARTICLE / ARTIGO ESPECIAL

\title{
The COVID-19 pandemic and changes in the lifestyles of Brazilian adolescents
}

\section{A pandemia de COVID-19 e mudanças nos estilos de vida dos adolescentes brasileiros}

\author{
Deborah Carvalho Malta',"I (D), Crizian Saar Gomes' (D, Marilisa Berti de Azevedo Barros "II (D), \\ Margareth Guimaraes Limall' (D), Alanna Gomes da Silvall (D), \\ Laís Santos de Magalhães Cardoso" (D), André Oliveira Werneck ${ }^{\mathrm{IV}}$ (D), \\ Danilo Rodrigues Pereira da Silvav (iD, Arthur Pate de Souza Ferreiravi (iD, \\ Dália Elena RomerovI (D), Maria Imaculada de Fátima Freitas"II (D), Ísis Eloah MachadovII (D), \\ Paulo Roberto Borges de Souza Júnior ${ }^{\mathrm{VI}}$ (D), Giseli Nogueira DamacenaVI (D), \\ Luiz Otávio Azevedovi (D), Wanessa da Silva de Almeidavi (iD, \\ Célia Landmann Szwarcwald ${ }^{\mathrm{VI}}$ (iD)
}

\begin{abstract}
Objective: To analyze changes in the lifestyles of Brazilian adolescents during the COVID-19 pandemic. Methods: Cross-sectional study carried out with adolescents who participated in the survey "ConVid Adolescentes - Pesquisa de Comportamentos". The indicators related to lifestyles before and during the COVID-19 pandemic were evaluated: consumption of healthy and unhealthy foods, physical activity and sedentary behavior, smoking and consumption of alcohol. Prevalence and $95 \%$ confidence intervals were calculated for the total population and according to sex and age group. Results: A total of 9,470 adolescents participated in the study. During the period of social distancing, there was an increase in the prevalence of vegetables consumption (from 27.34 to $30.5 \%$ ), frozen foods (from 13.26 to $17.3 \%$ ), chocolates and sweets (from 48.58 to $52.51 \%$ ), and time in front of screens (from 44.57 to $70.15 \%$ ). On the other hand, there was a decrease in the practice of physical activity (from 28.70 to $15.74 \%$ ) and in the consumption of alcohol (from 17.72 to $12.77 \%$ ). Differences were observed according to sex and age group. Conclusion: The results show changes in the lifestyle of adolescents and an increase in health risk behaviors.
\end{abstract}

Keywords: Coronavirus infections. Social isolation. Lifestyle. Adolescent.

'Postgraduate Program in Public Health, Universidade Federal de Minas Gerais - Belo Horizonte (MG), Brazil

"Postgraduate Program in Nursing, School of Nursing, Universidade Federal de Minas Gerais - Belo Horizonte (MG), Brazil.

"'School of Medical Sciences, Universidade Estadual de Campinas - Campinas (SP), Brazil.

IvSchool of Public Health, Universidade de São Paulo - São Paulo (SP), Brazil.

vDepartment of Physical Education, Universidade Federal de Sergipe - São Cristóvão (SE), Brazil.

VIInstitute of Communication and Scientific and Technological Information in Health, Fundação Oswaldo Cruz - Rio de Janeiro (RJ), Brazil.

VIISchool of Medicine, Universidade Federal de Ouro Preto - Ouro Preto (MG), Brazil.

Corresponding author: Deborah Carvalho Malta. Avenida Professor Alfredo Balena, 190, Santa Efigênia, CEP: 30130-100, Belo Horizonte (MG), Brazil. E-mail: dcmalta@uol.com.br

Conflict of interests: nothing to declare - Financial support: none. 
RESUMO: Objetivo: Analisar as mudanças nos estilos de vida dos adolescentes brasileiros durante a pandemia de COVID-19. Métodos: Estudo transversal realizado com adolescentes que participaram do inquérito ConVid Adolescentes - Pesquisa de Comportamentos. Foram avaliados os indicadores relacionados aos estilos de vida antes e durante a pandemia: consumo de alimentos saudáveis e alimentos não saudáveis, prática de atividade física e comportamento sedentário, tabagismo e consumo de bebidas alcoólicas. As prevalências e os intervalos de confiança de $95 \%$ (IC95\%) foram calculados para população total e segundo sexo e faixa etária. Resultados: Participaram do estudo 9.470 adolescentes. Durante o período de distanciamento social, foi observado aumento nas prevalências de consumo de hortaliças (de 27,34 para 30,5\%), pratos congelados (de 13,26 para 17,3\%), chocolates e doces (de 48,58 para 52,51\%), e do tempo em frente às telas (de 44,57 para 70,15\%). Por outro lado, houve diminuição da prática de atividade física (de 28,7 para 15,74\%) e do consumo de bebidas alcoólicas (de 17,72 para 12,77\%). Diferenças segundo sexo e faixa etária foram observadas. Conclusão: Os resultados apontam mudanças nos estilos de vida dos adolescentes e aumento de comportamentos de risco à saúde.

Palavras-chave: Infecções por coronavírus. Isolamento social. Estilo de vida. Adolescente.

\section{INTRODUCTION}

In order to halt the COVID-19 pandemic, caused by the novel coronavirus (SARS-CoV-2), public health measures were adopted, including social distancing, in order to reduce physical contact between people and the risk of virus transmission, in addition to assist in reducing cases. ${ }^{1}$

Social distancing is the most effective measure for preventing COVID-19. ${ }^{2}$ However, it is a difficult experience to face and can have significant impacts on everyone's lives. ${ }^{3,4}$ The pandemic also caused significative socioeconomic impacts in the world and in Brazil, with loss of family income and unemployment, aggravating social and health inequalities., ${ }^{5,6}$

Studies on the effect of social distancing on the lives of adolescents and children are still scarce. The isolation from loved ones, friends, and teachers, the loss of freedom, uncertainty about the disease, changes in routine activities, lack of physical space at home, aspects related to the financial worsening of families and the interruption of classes can cause changes in behaviors and lifestyles, and can damage the health of children and adolescents. ${ }^{7,8}$

Evidence suggests that when children and adolescents are out of school (for example, during weekends and holidays), they are physically less active, more screen time, have sleep problems, and worsen their diet, which results in weight gain and loss of cardiorespiratory fitness. ${ }^{8,9}$ Thus, during the period of social distancing, the effects on adolescents' health are likely to be more intense, as young people are isolated at their homes, with no outdoor activities and interaction with friends. A study carried out with children and adolescents during the COVID-19 pandemic in Italy showed an increase in the consumption of ultra-processed foods, a reduction in the time spent in sports activities, and an increase in screen time. ${ }^{10}$ 
In this context, knowing the impact of the ongoing pandemic on the health of Brazilian adolescents is extremely necessary to subsidize and guide the health actions directed at this group, aiming to minimize the adverse effects brought about by the prolonged social distancing. Thus, the objective of this study was to analyze changes in the lifestyles of Brazilian adolescents during the COVID-19 pandemic.

\section{METHODS}

This is a cross-sectional study conducted with Brazilian adolescents aged 12 to 17, who participated in the virtual health survey called ConVid Adolescents - Survey on Behaviors (ConVid Adolescentes - Pesquisa de Comportamentos), which aimed to assess the changes that occurred in the lives of Brazilian adolescents during the isolation period, a consequence of the COVID-19 pandemic in the country.

Data collection of ConVid Adolescents took place via the web with a self-administered questionnaire, using a smartphone or computer with Internet access. The questionnaire was built using the RedCap application (Research Electronic Data Capture) and addressed questions about sociodemographic characteristics and changes in lifestyles, routine activities, mood, and family relationships during the period of social distancing. Information was collected directly through the Internet and stored on the server of the Institute of Communication and Scientific and Technological Information in Health of Fundação Oswaldo Cruz (ICICT/Fiocruz). All responses were anonymous, and participants did not have to identify themselves. More details about the survey can be found on the official website of ConVid Adolescents - Survey on Behaviors. ${ }^{11}$

The invitation made to participants occurred though a chain sampling procedure called virtual "snowball". ${ }^{12}$ In the first stage, researchers carrying out the study chose a total of 15 other researchers from different states in Brazil, with previous experience in studies with adolescents. They sent the survey link to 20 or 30 adults from their social networks who had teenage children. These adults were asked to invite at least three more parents or guardians of teenagers. Thus, the invitations sent asked: "Do you have children or are you responsible for young people aged 12 to 17 years old?" Only those who answered affirmatively received the free and informed consent form (ICF) with explanations about the study, a link to contacts and clarifications about research, and the request for consent for the participation of the minor under their responsibility. After acceptance by the responsible adult, the adolescent received a free and informed consent form (ICF). Only after accepting the ICF, the respondent started filling out the questionnaire. In addition, the research coordination sent letters to the departments of State Secretariats and schools inviting them to forward the link to parents and adolescents in their respective school communities. With this methodology, the sample obtained was 9,470 adolescents aged 12 to 17 years old, from June 27 to October 12, 2020.

Since sampling by networks is not probabilistic, in order to obtain a representative sample of the population, according to geographic location and sociodemographic characteristics, 
weights were calculated using post-stratification procedures. ${ }^{13}$ The sample was calibrated using data from the Brazilian National Survey on Students' Health (Pesquisa Nacional de Saúde do Escolar - PeNSE), conducted by the Brazilian Institute of Geography and Statistics (Instituto Brasileiro de Geografia e Estatística - IBGE) in partnership with the Ministry of Health, to obtain the same distribution by region of residence, sex, age group ( 12 to $15 ; 16$ to 17 ), and type of school (public; private). ${ }^{14}$

In the present study, indicators related to lifestyles before and during the COVID-19 pandemic were evaluated, namely:

- Eating habits

- Healthy foods:

- Regular fruit consumption: percentage of adolescents who reported consuming fruit on at least five of the seven days of the week; ${ }^{14}$

- Regular vegetable consumption: percentage of adolescents who reported consuming vegetables on at least five of the seven days of the week. ${ }^{14}$

- Unhealthy foods:

- Frozen food consumption: percentage of adolescents who reported consuming frozen foods (for example, pizza, lasagna, or other frozen ready dish) on two or more days of the week; ${ }^{15}$

Chocolate and sweet consumption: percentage of adolescents who reported consuming chocolates and sweets on two or more days of the week; ${ }^{15}$

Potato chips consumption: percentage of adolescents who reported consuming potato chips on two or more days of the week. ${ }^{15}$

Food consumption variables were assessed by the following questions:

"Usually, before the COVID-19 pandemic, on how many days of the week did you usually eat these foods?";

"During the COVID-19 pandemic, on how many days of the week did you start eating these foods?”.

- Physical activity

- Enough physical activity: percentage of adolescents who reported practicing physical activity for at least one hour on five or more days of the week, that is, at least 300 minutes per week. ${ }^{14}$ This indicator was evaluated by the following questions:

"Before the COVID-19 pandemic, on how many days did you do physical activity for at least 60 minutes (one hour) a day? For example: playing sports, playing ball, riding a bicycle, walking, running, taking a Physical Education class, going to school walking or cycling (add all the time you spent on any type of physical activity, on each day);"

"During the COVID-19 pandemic, on how many days did you do physical activity for at least 60 minutes (one hour) a day? (add all the time you spent on any type of physical activity, on each day)." 
- Sedentary behavior: percentage of students who reported spending three or more hours a day sitting watching television, playing video games, using a computer, cell phone and/or tablet, or doing other sitting activities, based on the questions:

"Before the COVID-19 pandemic, how many hours a day did you used to sit watching television, playing video games, using a computer, cell phone, tablet, or doing other activities while sitting down? (DO NOT count Saturdays, Sundays, holidays, or sitting at school);"

"During the COVID-19 pandemic, how many hours a day do you sit watching television, playing video games, using a computer, cell phone, tablet, or doing other activities while sitting? (DO NOT count Saturdays, Sundays, holidays, or sitting time at school or during distance learning activities).” 14

- Tobacco use: percentage of adolescents who consume tobacco. The following questions were used to compose this indicator:

"Before the COVID-19 pandemic, did you used to smoke cigarettes? (Yes / No);" "And during the COVID-19 pandemic? 1 - I didn't smoke cigarettes; 2 - I am smoking less than I used to; 3 - I continued smoking with the same frequency; 4 - I am smoking more than I used to; 5 - I had stopped smoking, but I started smoking again."

In this indicator, adolescents who answered "yes" to the first question and to options 2 , 3,4 , or 5 in the second question were classified as smokers.

- Consumption of alcohol: percentage of adolescents who reported consuming alcohol. The following questions were assessed:

- "Before the COVID-19 pandemic, did you used to drink alcohol at parties, going out with friends, etc.? (Yes/No);"

- "And during the COVID-19 pandemic? 1 - I did not drink alcohol; 2 - I am drinking less alcohol than I used to; 3 - I continued to drink alcohol with the same frequency; 4 - I am drinking more alcohol than I used to."

In this indicator, adolescents who answered "yes" to the first question and to options 2, 2,3 , or 4 in the second question were classified as consumers of alcohol.

In this study, the prevalence and respective $95 \%$ confidence intervals $(95 \% \mathrm{CI})$ of the variables studied were calculated before and during the COVID-19 pandemic. The analyzes were stratified by sex (male; female) and age group (12 to 15; 16 to 17). To assess the differences between prevalence before and during the COVID-19 pandemic, the McNemar's test was used, with $\mathrm{p}<0.05$ being considered significant.

Research was approved by the National Research Ethics Commission (Opinion No. 4.100.515). Parents or guardians of adolescents previously completed the ICF, followed by the consent of adolescents themselves. There was no identification of research participants. 


\section{RESULTS}

In this study, 9,470 adolescents were evaluated, of which $50.25 \%$ (95\%CI $48.58-51.91)$ were female, $67.68 \%(95 \% \mathrm{CI} 66.28-69.05)$ were between 12 and 15 years old, and $32.32 \%$ (95\%CI $30.95-33.72)$, between 16 and 17 years old.

Table 1 shows the prevalence of consumption of healthy and unhealthy foods before and during the COVID-19 pandemic. Among the total number of adolescents, there was an increase in the regular consumption of vegetables (from 27.34 to $30.50 \%$ ), as well as among females and males and all age groups. As to fruit consumption, when compared before and during the pandemic, the prevalence remained stable, except for females, in which there was an increase. On the other hand, the consumption of unhealthy foods increased for the total number of adolescents, of both sexes and age groups - frozen foods (from 13.26 to $17.30 \%$ ), and chocolates and sweets (from 48.58 to $52.51 \%$ ). The consumption of potato chips decreased for the total population and in the age group of 12 to 15 (from 25.14 to $24.22 \%$ ) and increased for the age group of 16 to 17 during the COVID-19 pandemic.

Regarding the practice of physical activity, the prevalence before the pandemic was $28.7 \%$ and during the pandemic, $15.74 \%$. This decrease also occurred in both sexes and age groups. On the other hand, sedentary behavior increased from 44.57 to $70.15 \%$ among the total number of adolescents, in both sexes and age groups (Table 2).

Regarding tobacco use, $2.58 \%$ of adolescents mentioned using it before the pandemic, and there was no variation in its consumption during the pandemic. As to the consumption of alcohol, $17.72 \%$ of the adolescents reported that they consumed them before the pandemic, a percentage that decreased to $12.77 \%$ during the pandemic. This behavior was also observed in both sexes and age groups (Table 3 ).

\section{DISCUSSION}

To the best of our knowledge, this is the first survey to assess changes in the lifestyle of Brazilian adolescents during social distancing, as a result of the COVID-19 pandemic. The changes observed were increased consumption of vegetables and unhealthy foods, such as frozen foods, chocolates and sweets; reduced consumption of potato chips; reduction in physical activity; and increased sedentary behavior. There was no change in tobacco use and there was a decrease in the consumption of alcohol.

Data from ConVid Adolescentes pointed out that $70 \%$ of adolescents adhered to social distancing during the COVID-19 pandemic, following the behavior of adults, a segment in which approximately $75 \%$ adhered to this practice. ${ }^{16}$ These results show that adolescents had good adherence to social distancing.

Social distancing is known for being the most widespread measure adopted by authorities, and one of the most efficient measures to prevent the spread of the disease and 
Table 1 Consumption of healthy foods and unhealthy foods before and during the COVID-19 pandemic, according to sex and age group Brazil, 2020.

\begin{tabular}{|c|c|c|c|c|}
\hline \multicolumn{2}{|c|}{ Variables } & $\begin{array}{c}\text { Before the pandemic - } \\
\quad \%(95 \% \mathrm{Cl})\end{array}$ & $\begin{array}{l}\text { During the pandemic - } \\
\qquad \%(95 \% \mathrm{Cl})\end{array}$ & p-value \\
\hline \multicolumn{5}{|c|}{ Regular consumption of vegetables } \\
\hline & Total & $27.34(25.97-28.76)$ & $30.5(29.03-32.01)$ & $<0.001$ \\
\hline \multirow{2}{*}{ Sex } & Female & $28.52(26.89-30.22)$ & $32.58(30.82-34.39)$ & $<0.001$ \\
\hline & Male & $26.15(23.97-28.45)$ & $28.38(26.06-30.82)$ & $<0.001$ \\
\hline \multirow{2}{*}{ Age } & 12 to 15 & $27.81(26.01-29.69)$ & $30.95(29.02-32.95)$ & $<0.001$ \\
\hline & 16 to 17 & $26.36(24.43-28.39)$ & $29.55(27.52-31.67)$ & $<0.001$ \\
\hline
\end{tabular}

Regular consumption of fruit

\begin{tabular}{l|c|c|c|c|}
\hline & Total & $30.89(29.37-32.46)$ & $31.56(30.05-33.12)$ & 0.168 \\
\hline \multirow{2}{*}{ Sex } & Female & $30.54(28.81-32.32)$ & $32.02(30.25-33.83)$ & 0.020 \\
\cline { 2 - 6 } & Male & $31.25(28.77-33.85)$ & $31.1(28.66-33.66)$ & 0.603 \\
\hline \multirow{2}{*}{ Age } & 12 to 15 & $32.58(30.56-34.66)$ & $32.92(30.92-34.99)$ & 0.625 \\
\cline { 2 - 6 } & 16 to 17 & $27.37(25.35-29.50)$ & $28.73(26.68-30.87)$ & 0.102 \\
\hline
\end{tabular}

Inadequate consumption of frozen foods

\begin{tabular}{l|c|c|c|c}
\hline & Total & $13.26(12.11-14.51)$ & $17.3(16.08-18.59)$ & $<0.001$ \\
\hline \multirow{2}{*}{ Sex } & Female & $12.93(11.74-14.22)$ & $18.29(16.94-19.73)$ & $<0.001$ \\
\cline { 2 - 6 } & Male & $13.6(11.66-15.81)$ & $16.28(14.28-18.50)$ & $<0.001$ \\
\hline \multirow{2}{*}{ Age } & 12 to 15 & $13.39(11.85-15.10)$ & $16.53(14.94-18.25)$ & $<0.001$ \\
\hline & 16 to 17 & $13.0(11.58-14.56)$ & $18.91(17.21-20.75)$ & $<0.001$ \\
\hline
\end{tabular}

Inadequate consumption of potato chips

\begin{tabular}{c|c|c|c|c|}
\hline & Total & $25.14(23.65-26.69)$ & $24.22(22.78-25.73)$ & 0.029 \\
\hline \multirow{3}{*}{ Sex } & Female & $27.39(25.66-29.18)$ & $26.56(24.87-28.33)$ & 0.175 \\
\cline { 2 - 6 } & Male & $22.86(20.47-25.44)$ & $21.85(19.54-24.35)$ & 0.084 \\
\hline \multirow{2}{*}{ Age } & 12 to 15 & $26.08(24.10-28.16)$ & $23.93(22.03-25.94)$ & $<0.001$ \\
\cline { 2 - 6 } & 16 to 17 & $23.17(21.25-25.21)$ & $24.83(22.84-26.94)$ & 0.045 \\
\hline
\end{tabular}

Inadequate consumption of chocolates and sweets

\begin{tabular}{l|c|c|c|c}
\hline & Total & $48.58(46.92-50.24)$ & $52.51(50.83-54.17)$ & $<0.001$ \\
\hline \multirow{2}{*}{ Sex } & Female & $54.98(53.12-56.84)$ & $58.06(56.19-59.90)$ & $<0.001$ \\
\cline { 2 - 6 } & Male & $42.08(39.39-44.82)$ & $46.86(44.12-49.63)$ & $<0.001$ \\
\hline \multirow{2}{*}{ Age } & 12 to 15 & $47.63(45.44-49.84)$ & $52.03(49.82-54.23)$ & $<0.001$ \\
\cline { 2 - 6 } & 16 to 17 & $50.56(48.26-52.85)$ & $53.51(51.20-55.80)$ & 0.001 \\
\hline
\end{tabular}

95\% Cl: 95\% confidence interval. 
Table 2 Physical activity and sedentary behavior before and during the COVID-19 pandemic, according to sex and age group Brazil, 2020.

\begin{tabular}{|c|c|c|c|c|}
\hline \multicolumn{2}{|c|}{ Variables } & $\begin{array}{c}\text { Before the pandemic - } \\
\qquad \%(95 \% \mathrm{Cl})\end{array}$ & $\begin{array}{c}\text { During the pandemic - } \\
\qquad \%(95 \% \mathrm{Cl})\end{array}$ & p-value \\
\hline \multicolumn{5}{|c|}{ Enough physical activity } \\
\hline & Total & $28.70(27.24-30.20)$ & $15.74(14.58-16.98)$ & $<0.001$ \\
\hline \multirow{2}{*}{ Sex } & Female & $24.95(23.35-6.62)$ & $16.41(14.99-17.93)$ & $<0.001$ \\
\hline & Male & $32.51(30.07-35.05)$ & $15.06(13.26-17.07)$ & $<0.001$ \\
\hline \multirow{2}{*}{ Age } & 12 to 15 & $27.78(25.90-29.74)$ & $14.88(13.39-16.50)$ & $<0.001$ \\
\hline & 16 to 17 & $30.61(28.49-32.82)$ & $17.55(15.83-19.40)$ & $<0.001$ \\
\hline \multicolumn{5}{|c|}{ Sedentary behavior ( $\geq 3$ hours) } \\
\hline & Total & $44.57(42.92-46.23)$ & $70.15(68.56-71.70)$ & $<0.001$ \\
\hline \multirow{2}{*}{ Sex } & Female & $43.46(41.72-45.42)$ & $70.79(68.96-72.55)$ & $<0.001$ \\
\hline & Male & $45.59(42.85-48.35)$ & $69.51(66.87-72.03)$ & $<0.001$ \\
\hline \multirow{2}{*}{ Age } & 12 to 15 & $43.99(41.81-46.19)$ & $68.08(65.94-70.14)$ & $<0.001$ \\
\hline & 16 to 17 & $45.78(43.51-48.08)$ & $74.49(72.41-76.46)$ & $<0.001$ \\
\hline
\end{tabular}

95\% $\mathrm{Cl}: 95 \%$ confidence interval.

Table 3 Alcohol and tobacco use before and during the COVID-19 pandemic, according to sex and age group Brazil, 2020.

\begin{tabular}{|c|c|c|c|c|}
\hline \multicolumn{2}{|c|}{ Variables } & $\begin{array}{c}\text { Before the pandemic - } \\
\qquad \%(95 \% \mathrm{Cl})\end{array}$ & $\begin{array}{l}\text { During the pandemic - } \\
\qquad \%(95 \% \mathrm{Cl})\end{array}$ & p-value \\
\hline \multicolumn{5}{|c|}{ Tobacco use } \\
\hline & Total & $2.58(2.17-3.10)$ & $2.41(2.02-2.87)$ & 0.294 \\
\hline \multirow{2}{*}{ Sex } & Female & $2.16(1.69-2.76)$ & $2.05(1.64-2.60)$ & 0.590 \\
\hline & Male & $3.01(2.35-3.83)$ & $2.77(2.14-3.57)$ & 0.359 \\
\hline \multirow{2}{*}{ Age } & 12 to 15 & $2.11(1.63-2.73)$ & $2.05(1.59-2.62)$ & 0.799 \\
\hline & 16 to 17 & $3.56(2.85-4.44)$ & $3.16(2.49-4.00)$ & 0.175 \\
\hline \multicolumn{5}{|c|}{ Consumption of alcohol } \\
\hline & Total & $17.72(16.64-18.85)$ & $12.77(11.85-13.76)$ & $<0.001$ \\
\hline \multirow{2}{*}{ Sex } & Female & $20.38(18.99-21.85)$ & $14.15(12.99-15.40)$ & $<0.001$ \\
\hline & Male & $15.01(13.43-16.75)$ & $11.37(9.98-12.92)$ & $<0.001$ \\
\hline \multirow{2}{*}{ Age } & 12 to 15 & $11.56(10.38-12.87)$ & $8.55(7.52-9.71)$ & $<0.001$ \\
\hline & 16 to 17 & $30.61(28.61-32.68)$ & $21.61(19.90-23.43)$ & $<0.001$ \\
\hline
\end{tabular}

95\% $\mathrm{Cl}: 95 \%$ confidence interval. 
reduce the cases of COVID-19. ${ }^{17}$ However, this practice directly affects behavioral changes and the population's lifestyle. ${ }^{3,4,18}$ The changes in lifestyles and the adoption of unhealthy habits, which occurred during the period of social distancing, can damage the health of adolescents. ${ }^{19}$

As to eating habits, there was an increase in the regular consumption of vegetables for all ages and sexes in the present study, as well as a reduction in the consumption of potato chips for the total population and the 12 to 15 age group. On the other hand, there was an increase in the consumption of frozen foods, chocolates and sweets, and potato chips among adolescents aged 16 to 17 . The consumption of fruits and vegetables is a protective factor against cardiovascular diseases and type II diabetes. ${ }^{20}$ Such prevalence were similar to those found in PeNSE, carried out in 2012, in which fruit consumption among adolescents, on five days a week, was $29.8 \%(95 \%$ CI $29.1-30.5) .{ }^{21}$ However, this consumption is lower when compared to other European countries, such as Belgium, which reaches about $50 \%{ }^{22}$

The results seen during the COVID-19 pandemic can be explained by the fact that children and adolescents, when staying at home, consume the food prepared at home, maintaining and expanding the consumption of healthy foods, such as vegetables. However, in parallel, there was also an increase in the consumption of some unhealthy foods, such as frozen foods, which may be related to their practicality and ease of preparation. Similar results were observed in a longitudinal study carried out in Verona, Italy, with 41 obese children, which identified that, during the quarantine caused by the COVID-19 pandemic, there were no changes in vegetable intake, and fruit consumption increased. On the other hand, the consumption of fries and red meat, as well as of sugary drinks increased significantly. ${ }^{10}$ In this sense, the present study identified a certain paradox in adolescents' diets, since they consume both healthy and unhealthy foods concomitantly. The same situation had already been identified with PeNSE data, in which three dietary patterns were identified: healthy $(27.7 \%)$, unhealthy $(34.6 \%)$, and mixed (37.7\%), this last indicating the consumption of both types of food (healthy and unhealthy). ${ }^{23}$ Therefore, this mixed eating pattern did not change during the COVID-19 pandemic.

The reduction in the practice of physical activity and the increase in sedentary behavior among the adolescents observed in the present study are worrisome. The same conclusions were obtained in a study conducted in Verona, Italy, during the first wave of the COVID-19 pandemic, pointing out that the time spent on sports activities during the pandemic decreased by 2.30 hours per week; sleep time increased by 0.65 hours per day; and screen time increased by 4.85 hours a day. ${ }^{10}$ In addition, the data found in the present study are similar to that of global studies, which showed most teenagers remained isolated at home during the period of social distancing, without conducting outdoor activities and having no interaction with their friends - which resulted in a reduction in sports practices and time in physical activity, and in worsening sedentary habits, such as time in front of the computer and TV screens.

The results indicated may have intense repercussions on health, in addition to changes in anthropometric measures. Regular practice of physical activity in adolescents influences 
physical and bone development, in addition to increasing the chance of becoming active adults. ${ }^{21,24,25}$ In addition, the World Health Organization (WHO) recommends that children and adolescents do not spend more than two hours in front of the TV. Sedentary behavior, in addition to increasing cardiovascular risk, decreases energy expenditure and is generally associated with the consumption of caloric foods and soft drinks. ${ }^{26}$ The current study adopted the cutoff point used by the WHO, that is, three hours for sedentary leisure, which includes screen time and other leisure activities considered sedentary, such as talking sitting. ${ }^{27}$ This time practically doubled during the COVID-19 pandemic, revealing concerns about changing habits.

As to tobacco use, there was no change before and during the pandemic. However, tobacco is one of the most important risk factors for the onset of most chronic diseases, making it relevant to prevent and delay initiation to the habit to reduce the harmful effects of smoking on adolescents. ${ }^{28,29}$ The prevalence of smoking among adolescents found in the present study is lower than that observed in PeNSE in 2015 (5.6\%; 95\%CI 5.3 - 5.9), which can mean both a reduction in consumption in this age group and the fact that they remain at home, without interaction with friends and acquaintances,${ }^{21}$ and with greater difficulty in obtaining or buying cigarettes.

In the present study, the consumption of alcohol decreased among adolescents during the COVID-19 pandemic. The consumption of alcohol by adolescents is not recommended for being a significative risk factor for accidents, violence, depressive disorders, anxiety, fights at school, bullying, chronic diseases, in addition to being a predictor of the consumption of alcohol in adulthood. ${ }^{30-32}$ Its consumption among Brazilian adolescents is high (about $\left.25 \%\right)^{30,33}$ and is associated with socialization practices, and parties and celebrations with friends. ${ }^{31}$ Analysis of PeNSE data shows that parties were the main means of obtaining alcoholic beverages by girls (44\%), followed by through friends $(23 \%){ }^{32}$ Thus, the fact that adolescents adhere to social distancing, staying at home, without participating in parties and without physical contact with friends, was possibly the main responsible for the reduction of the consumption of alcohol during the COVID-19 pandemic.

Among the study limitations, data collection over the Internet is discussed, which may not reach all population strata, considering that not everyone has access to this means of communication - a fact that can lead to under or overestimation of these indicators' ratio. This limitation was minimized due to the sample calibration with PeNSE data. Another limitation refers to the fact that data collection was carried out from June 27 to October 12, 2020, during a singular moment of social distancing, subject to changes throughout the course of the ongoing pandemic. In addition, information about the pre-pandemic period was collected during the pandemic, which may be subject to memory bias. Data collection via the Internet and the chain sampling process are ethically plausible methods when considering the pandemic context, in addition to the low cost related to operationalization. Online surveys have emerged as a promising method for assessing and tracking knowledge, behaviors, lifestyles, and perceptions during outbreaks of rapidly evolving infectious diseases. 
The data presented in this study suggest a change in behavior among Brazilian adolescents during the pandemic, such as increased consumption of frozen foods, sweets and chocolates, as well as sedentary behavior, and reduced physical activity. However, during the pandemic period, vegetable consumption increased, and consumption of potato chips and alcohol decreased. The support of family members becomes important, as well as public policies that reinforce healthy behaviors and continuity of care, especially among adolescents.

\section{REFERENCES}

1. World Health Organization (WHO). Coronavirus disease (COVID-19) Pandemic. [Internet]. World Health Organization; 2020 [accessed on Nov 10, 2020]. Available at: https: / / www.who.int/emergencies / diseases/novel-coronavirus-2019

2. Minas Gerais. State Secretariat. Entenda a importância do distanciamento social. [Internet]. Minas Gerais: Secretaria do Estado; 2020 [accessed on Nov 10, 2020]. Available at: https: / coronavirus.saude.mg.gov.br/ blog/108-distanciamento-social\#: : text $=\mathrm{O} \% 20$ distanciamento $\% 20$ social $\% 20 \%$ C3\%A9\%20 uma,conhecido $\% 20$ como $\% 200 \% 20$ novo $\% 20$ coronav\%C3\%ADrus

3. Malta DC, Szwarcwald CL, Barros MBA, Gomes CS, Machado IE, Souza Júnior PRB, et al. A pandemia da COVID-19 e as mudanças no estilo de vida dos brasileiros adultos: um estudo transversal, 2020. Epidemiol Serv Saúde 2020; 29(4): e2020407. https: / / doi.org/10.1590/s1679-49742020000400026

4. Malta DC, Gomes CS, Szwarcwald CL, Barros MBA, Silva AG, Prates EJS, et al. Distanciamento social, sentimento de tristeza e estilos de vida da população brasileira durante a pandemia de COVID19. Saúde Debate 2020; 44(4): 177-90. https:/ / doi. org/10.1590/0103-11042020E411

5. Dorn AV, Cooney RE, Sabin ML. COVID-19 exacerbating inequalities in the US. SLancet 2020; 388(10053): 12434. https: / doi.org/10.1016/s0140-6736(20)30893-x

6. Instituto Brasileiro de Geografia e Estatística (IBGE). PNAD COVID-19. [Internet]. Instituto Brasileiro de Geografia e Estatística; 2020 [accessed on Jan 12, 2020]. Available at: https: / / covid19.ibge.gov.br/pnad-covid/

7. Wang G, Zhang Y, Zhao J, Zhang J, Jiang F. Mitigate the effects of home confinement on children during the COVID-19 outbreak. Lancet 2020; 395(10228): 945 47. https:// doi.org/10.1016/S0140-6736(20)30547-X
8. Wang G, Zhang J, Lam SP, Li SX, Jiang Y, Sun W, et al. Ten-Year Secular Trends in Sleep/Wake Patterns in Shanghai and Hong Kong School-Aged Children: A Tale of Two Cities. J Clin Sleep Med 2019; 15(10): 1495-502. https: / / doi.org/10.5664/jcsm.7984

9. Brazendale K, Beets MW, Weaver RG, Pate RR, TurnerMcGrievy GM, Kaczynski AT, et al. Understanding differences between summer vs. school obesogenic behaviors of children: the structured days hypothesis. Int J Behav Nutr Phys Act 2017; 14: 100. https: / / doi. org/10.1186/s12966-017-0555-2

10. Pietrobelli A, Pecoraro L, Ferruzzi A, Heo M, Faith M, Zoller T, et al. Effects of COVID-19 Lockdown on Lifestyle Behaviors in Children with Obesity Living in Verona, Italy: A Longitudinal Study. Obesity 2020; 28(8): 1382-5. https: / / doi.org/10.1002/oby.22861

11. Fundação Oswaldo Cruz (Fiocruz). ConVid Adolescentes - Pesquisa de Comportamentos [Internet]. Fundação Oswaldo Cruz; 2020 [accessed on Jan 12, 2020]. Available at: https:// convid.fiocruz.br/

12. Costa BRL. Bola de neve virtual: o uso das redes sociais virtuais no processo de coleta de dados de uma pesquisa científica [Internet]. RIGS 2018 [accessed on Jan 12, 2020]; 7(1): 15-37. Available at: https://periodicos. ufba.br/index.php/rigs/article/view/24649

13. Szwarcwald CL, Damacena GN. Amostras complexas em inquéritos: planejamento e implicações na análise estatística de dados. Rev Bras Epidemiologia 2008; 11(Supl. 1): 38-45. https:// doi.org/10.1590/ S1415-790X2008000500004

14. Instituto Brasileiro de Geografia e Estatística (IBGE). Pesquisa nacional de saúde do escolar: 2015 [Internet]. Instituto Brasileiro de Geografia e Estatística; 2016 [accessed on Jan 12, 2020]. Available at: https:/ / www. ibge.govbr/estatisticas/sociais/educacao/9134-pesquisanacional-de-saude-do-escolar.html? $=\& \mathrm{t}=$ o-que-e 
15. World Health Organization (WHO). Diet, nutrition and the prevention of chronic diseases: report of a joint WHO/FAO expert consultation [Internet]. 2003 [accessed on Jan 12, 2020]. Available at: https: / / www.who.int/dietphysicalactivity/publications/ trs916/en/

16. Szwarcwald CL, Souza Júnior PRB, Malta DC, Barros MBA, Magalhães MAFM, Xavier DR, et al. Adesão às medidas de restrição de contato físico e disseminação da COVID-19 no Brasil. Epidemiol Serv Saúde 2020; 29(5): e2020432. https: / / doi.org/10.1590/ s1679-49742020000500018

17. Brasil. Ministério da Saúde. Medidas não farmacológicas [Internet]. Brasil: Ministério da Saúde; 2020 [accessed on Jan 12, 2020]. Available at: https:// coronavirus. saude.gov.br/medidas-nao-farmacologicas

18. Ahmed MZ, Ahmed O, Aibao Z, Hanbin S, Siyu L, Ahmad A. Epidemic of COVID-19 in China and associated psychological problems. Asian J Psychiatr 2020; 51: 102092. https://doi.org/10.1016/j. ajp.2020.102092

19. Di Renzo L, Gualtieri P, Pivari F, Soldati L, Attinà A, Cinelli G, et al. Eating habits and lifestyle changes during COVID-19 lockdown: an Italian survey. J Transl Med 2020; 18: 229. https: / / doi.org/10.1186/ s12967-020-02399-5

20. World Health Organization (WHO). Global status report on noncommunicable diseases 2010 [Internet]. World Health Organization; 2011 [accessed on Jan 12, 2020]. Available at: https:/ / www.who.int/nmh/ publications/ncd_report2010/en/

21. Malta DC, Andreazzi MAR, Oliveira-Campos M, Andrade SSCA, Sá NNB, Moura L, et al. Trend of the risk and protective factors of chronic diseases in adolescents, National Adolescent School-based Health Survey (PeNSE 2009 e 2012). Rev Bras Epidemiol 2014; 17(Supl. 1): 77-91. https://doi. org / 10.1590/1809-4503201400050007

22. World Health Organization(WHO). Social determinants of health and well-being among young people. Health Behaviour in School-aged Children (HBSC) study: international report from the 2009/2010 survey [Internet]. Copenhagen: WHO Regional Office for Europe; 2012 [accessed on Jan 12, 2020]. Available at: https://www.euro.who.int/_data/assets/pdf_ file/0003 / 163857 / Social-determinants-of-health-andwell-being-among-young-people.pdf

23. Tavares LF, Castro IRR, Levy RB, Cardoso LO, Claro RM. Padrões alimentares de adolescentes brasileiros: resultados da Pesquisa Nacional de Saúde do Escolar
(PeNSE). Cad Saúde Pública 2014; 30(12): 2679-90. https: / / doi.org/10.1590/0102-311x00016814

24. Gonçalves H, Hallal PC, Amorim TC, Araújo CLP, Menezes AMB. Fatores socioculturais e nível de atividade física no início da adolescência. Rev Panam Salud Pública [Internet] 2007 [acessado em 12 jan. 2020]; 22(4): 246-53. Available at: https:// iris.paho.org/bitstream/handle/10665.2/7775/04. pdf? sequence $=1$ \&isAllowed $=y$

25. SHallal PC, Knuth AG, Cruz DKA, Mendes MI, Malta DC. Prática de atividade física em adolescentes brasileiros. Ciênc Saúde Coletiva 2010; 15(Supl. 2): 3035 42. https: / / doi.org/10.1590/S1413-81232010000800008

26. United Nations Children's Fund (UNICEF). The State of the World's Children 2011. Adolescence: An Age of Opportunity [Internet]. Nova York: United Nations Children's Fund; 2011 [accessed on Jan 12, 2020]. Available at: https: / / www.unicef. org/sowc2011/pdfs / SOWC-2011-Main-Report_ EN_02092011.pdf

27. World Health Organization (WHO). Guidelines on physical activity, sedentary behavior and sleep [Internet]. World Health Organization; 2019 [accessed on Jan 12, 2020]. Available at: https: / / apps.who.int/ iris / bitstream/handle/10665/325147/WHO-NMHPND-2019.4-eng.pdf

28. Barreto SM, Giatti L, Casado L, Moura L, Crespo C, Malta DC. Exposição ao tabagismo entre escolares no Brasil. Ciênc Saúde Coletiva 2010; 15(Supl. 2): 3027-34. https:/ / doi.org/10.1590/S1413-81232010000800007

29. The Global Youth Tobacco Survey Collaborative Group. Tobacco use among youth: a cross country comparison. Special report. Tob Control 2002; 11(3): 252-70. https: / / doi.org/10.1136/tc.11.3.252

30. Strauch ES, Pinheiro RT, Silva RA, Horta BL. Uso de álcool por adolescentes: estudo de base populacional. Rev Saúde Pública 2009; 43(4): 647-55. https: / / doi. org/10.1590/S0034-89102009005000044

31. Malta DC, Mascarenhas MDM, Porto DL, Duarte EA, Sardinha LM, Barreto SM, et al. Prevalência do consumo de álcool e drogas entre adolescentes: análise dos dados da Pesquisa Nacional de Saúde Escolar. Rev Bras Epidemiol 2011; 14(Supl. 1): 136-46. https: / / doi. org/10.1590/S1415-790X2011000500014

32. Malta DC, Machado IE, Porto DL, Silva MMA, Freitas PC, Costa AWN, et al. Consumo de álcool entre adolescentes brasileiros segundo a Pesquisa Nacional de Saúde Escolar (PeNSE 2012). Rev Bras Epidemiol 2014; 17(Supl. 1): 203-14. https://doi. org/10.1590/1809-4503201400050016 
33. Malta DC, Machado IE, Felisbino-Mendes MSS, Prado RR, Pinto AMA, Oliveira-Campos M, et al. Uso de substâncias psicoativas em adolescentes brasileiros e fatores associados: Pesquisa Nacional de Saúde dos Escolares, 2015. Rev Bras Epidemiol 2018; 21(Supl. 1): e180004. https: / / doi. org/10.1590/1980-549720180004.supl.1

Received on: 01/16/2021

Reviewed on: 02/24/2021

Approved on: 03/01/2021

Preprint on: 03/10/2021
Authors' contribution: the authors contributed substantially to the study's conception and design; the acquisition, analysis, and interpretation of research data; the preparation of preliminary versions of the article and its critical review; approval of the final version to be published; and agreement on being responsible for all aspects of research to ensure that issues related to the accuracy or integrity, for all parts of the study be thoroughly investigated and resolved. 